\title{
Development of Comic Learning Media for Buying and Selling Practices on Social Arithmetic
}

\author{
Husnuz Zaimah \\ MTsN 2 Mojokerto, East Java
}

\begin{abstract}
This study was conducted to develop comic learning media which was valid, practical and effective to help students understand the concept of social arithmetic. This study is a developmental study which adapts stages of Borg and Gall. The stages are 1) initial study and gathering information, (2) planning, (3) developing the initial product, (4) limited field trial, (5) revising the initial product, (6) field trials, and (7) revision of the final product. The result of this study was a comic learning media for buying and selling practices on social arithmetic which has met the valid, practical, and effective criteria. Based on the validity results involving media and educational experts showed that this comic learning media was valid, with the percentage of validity respectively $93.6 \%$ (very feasible) and $96 \%$ (very feasible). Based on the implementation of this media to VII grade students of MTs N (junior high school) 2 Mojokerto, an assessment by students as the media users showed that this media was practical with the percentage of $82.3 \%$ (very good) during the limited field trial, and $92.31 \%$ (very good) during field trials. The effectiveness of this media based on students' achievement result that $91 \%$ students were in good and excellent category. It means that this comic learning media is effective. Based on these results, it can be concluded that this media was appropriate to be used as learning medium on the topic of social arithmetic.
\end{abstract}

Keywords: development, comic media, buying and selling practices.

\section{Introduction}

Formulation of mathematical discussion is not limited to determining relations, patterns, shapes and assemblies as targets. These four goals only emphasize that mathematics involves abstract ideas. Hudoyo (2013) stated that learning mathematics is a high mental activity. Thus, in the learning process of mathematics, the teacher must be able to provide good activities so that abstract mathematical concepts can be understood. In mathematics learning, it should also be noted that the activities or things students learn must be something interesting and challenging. As stated as one of the principles in school mathematics in the National Council of Mathematics Teachers, when learning is challenging, students will be confident to solve math problems and to understand new knowledge (NCTM, 2000). Learning media is one thing that can challenge and attract students' attention in learning mathematics.

There are so many types of media. According to Bretz (1971), in general, types of media can be divided into visual media, audio media and audiovisual media. As one of the visual media, comics are two-dimensional media in the form of sheets and contain several panels of textual images. Wright (1979) stated that comics as a medium of learning are something that can still attract children's attention. The use of comics as a medium will provide an opportunity for readers to form their own understanding after being interested in the visual 
appearance (McVicker, 2007). Specifically, comic as a learning media in mathematics learning can help students to prepare their competencies in $21{ }^{\text {st }}$ Century learning (Toh, Cheng, Ho, Jiang, \& Lim, 2017).

Comics as learning media as a packaged of picture and colored books that contain interactive dialogue pictures seems to has potential possibility to help students understand the concept of mathematics during the classroom activities. Some researches showed that comic media can improve students' learning achievement (Indaryati \& Jailani, 2015; Adi Widodo, Turmudi, Afgani Dahlan, Istiqomah, \& Saputro, 2018; Rasiman, \& Agnita, 2014; Sulistyani, $\&$ Retnawati, 2015). It means that comic seems to be a promising media that can help students understand mathematical concepts.

In social arithmetic material there are subjects of selling prices, buying prices, profits, loss, percentage and discounts. Based on the researcher experiences, many students got difficulties on this topic. It is supported by the research of Fajriah, Salasi, Suryawati, \& Fatimah (2019) that students may have some difficulties on it. On the formal textbook, the concept of social arithmetic is also presented in a mechanistic way (Fauzan, Armiati, \& Ceria, 2018). Hence, teacher needs to find a strategy to teach social arithmetic in order to help students understand the concept. Based on the mentioned fact, then researcher developed a comic as a learning medium that can effectively help students to understand the concept of social arithmetic.

\section{Methods}

This study is a type of research and development (R\&D). Borg and Gall (1983) stated the notion of research development is a process used to develop and validate educational products. The development procedure based on Borg and Gall's (1983) consist of 10 stages, namely (1) conducting research and information gathering, (2) planning, (3) developing initial product formats, (4) design validation, (5) making validation revisions design, (6) first trial (7) revising the product, (8) conducting a second trial (9) conducting an effectiveness test on the product, and (10) revising the final product. Then, adapted from Borg and Gall, the stages on this study are (1) initial study and gathering information, (2) planning, (3) developing the initial product, (4) limited field trial, (5) revising the initial product, (6) field trials, and (7) revision of the final product. The implementation of this comic media was conducted at MTs N 2 Mojokerto in March 2018 - May 2019 with research subjects in Class VII D, even semester, for the academic year of 2018/2019 and 2019/2020.

The assessment of the product in this development research involves experts (media experts and mathematics subject experts) to measure its validity. Furthermore, this study also involved students as users to measure its practicality. The effectiveness of the media is determined by carrying out implementation activities on 34 students and testing student learning outcomes after using this comic media to see the potential effect of the developed comic on learning achievements.

The research data consisted of qualitative and quantitative data. The qualitative data were obtained from the validator's suggestions and the students when determining the validity and practicality of the media. Quantitative data were obtained from validator assessment scores, student assessment questionnaires and student learning outcomes test scores. 
The instruments in this study include: (1) instruments for measuring validity in the form of an assessment sheet by a media expert and an assessment sheet by a material expert; (2) instruments to measure practicality, namely student practicality assessment sheets; (3) instruments to measure practicality, namely test questions for student learning outcomes.

The data obtained from each category were then analysed to obtain criteria for its validity, practicality, and effectiveness. Data validation scores from media experts and material experts, and media practicality scores from student assessments are then converted using a formula adapted from Akbar (2013) as follows:

$\mathrm{V}-\mathrm{ah}=\frac{T s e}{T s h} \times 100 \%$

(1)

$$
\mathrm{V}-\mathrm{au}=\frac{T s e}{T s h} \times 100 \%
$$

$\mathrm{V}-\mathrm{ah}=$ Percentage of Validity

$\mathrm{V}-\mathrm{au}=$ Percentage of Practicality

Tse $=$ Total empirical score achieved

Tsh $=$ Total expected score

$100=$ constant

The level of validity of the comic learning media is defined using the criteria on the following table. The media is stated as valid if the percentage of the expert's judgement at least meets "valid" criteria. Further, the comic media is said practical if the result of students' response is at least in "good" criteria.

Table 1

Criteria of Media's Validity and Practicality

\begin{tabular}{ccc}
\hline Percentage $(\boldsymbol{\%})$ & Level of Validity & Level of Practicality \\
\hline $85.01-100$ & Very valid & Very Good \\
$70.01-85$ & Valid & Good \\
$50.01-70$ & Less Valid & Fair \\
$01.00-50$ & Invalid & Poor
\end{tabular}

Adapted from Kristanto (2019)

The effectiveness of the media is defined based on the students result of learning achievement test. Adapted from Zainil, Prahmana, Helsa, and Hendri (2018), the media is said to be effective if most of students at least got "good" criteria of the learning result. 
Table 2

Criteria of Students' Learning Achievement

\begin{tabular}{cc}
\hline Score Interval $(\boldsymbol{x})$ & Criteria \\
\hline $80 \leq x<100$ & Excellent \\
$66 \leq x<80$ & Good \\
$56 \leq x<66$ & Fair \\
$40 \leq x<56$ & Poor \\
$0 \leq x<40$ & Failed
\end{tabular}

Adapted from Zainil, Prahmana, Helsa, and Hendri (2018)

\section{Results and Discussion}

There are 7 stages performed in this study namely: (1) initial study and gathering information, (2) planning, (3) developing the initial product, (4) limited field trial, (5) revising the initial product, (6) field trials, and (7) revision of the final product. The results on each stage are described as follow.

\section{Initial study and gathering information}

This stage included preliminary study to see the students' needs for learning media as well as gathering information (curriculum analysis for the preparation of the developed media). Researcher used questionnaire for students at MTs N 2 Mojokerto. Based on the results of the questionnaire, $85.92 \%$ of students showed high enthusiasm for comic-based learning media. Analysing the curriculum were done to select and to adjust the materials of buying and selling in social arithmetic in order to make the media appropriately with the Indonesian curriculum. Further, the analysis of the basic curriculum that can be achieved through this comics media were done as well as its learning objectives.

\section{Planning}

In the planning stage, the researcher arranged the flow of the developed comic. In addition, at this stage the researcher determines the application used, namely using the Comic Life 3 application. The following is an example of how the application looks. 


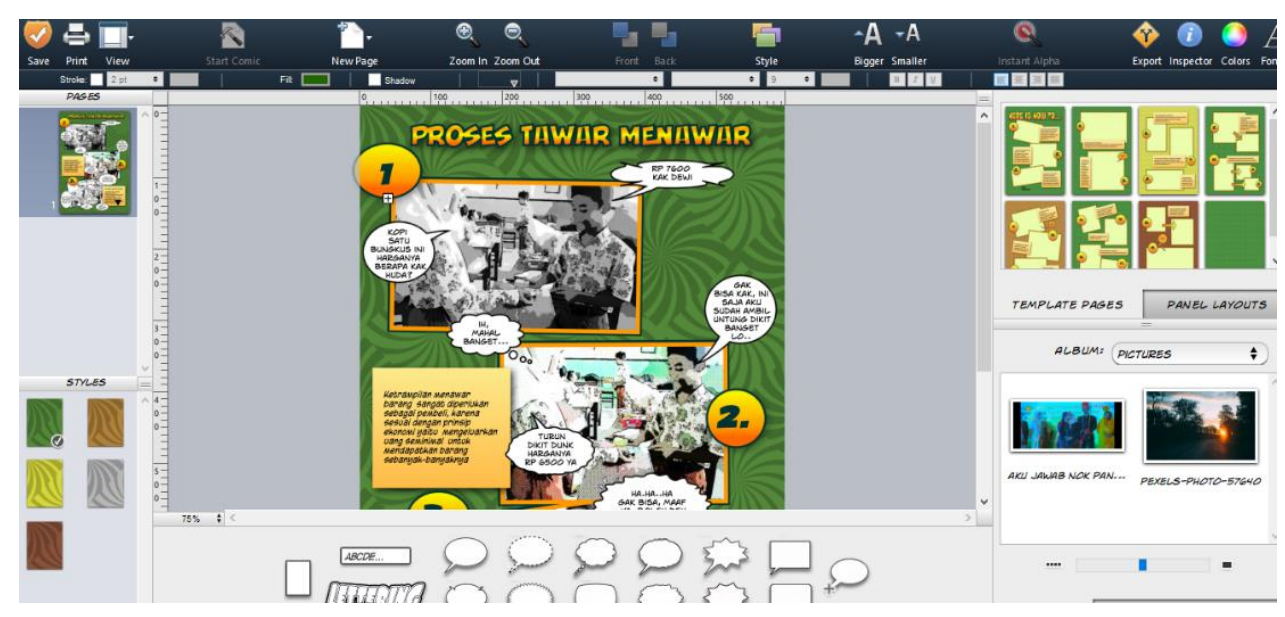

Figure 1. Interface of Comic Life 3 application.

At this planning stage, several materials needed in the comic development process were also collected. Because the comics were developed using real photos of students instead of pictures or animation, the researchers collected the photos needed to compile the comic story.

\section{Developing the initial product}

The researcher defined the specifications of the comic media. The product developed in this research specifications are as follows: (1) this product is based on multimedia using an Android-based and PC-based Comic Life 3 application ; (2) each page contains several panels featuring some scenes; (3) pictures used in the comic are non-fictional photographs; (4) contains balloon text in the form of a daily dialogue about the process of buying and selling practices on social arithmetic material; (4) inserting honest entrepreneurial principles into stories in comics. The prototype of the comic as the initial product can be seen on the figure below.

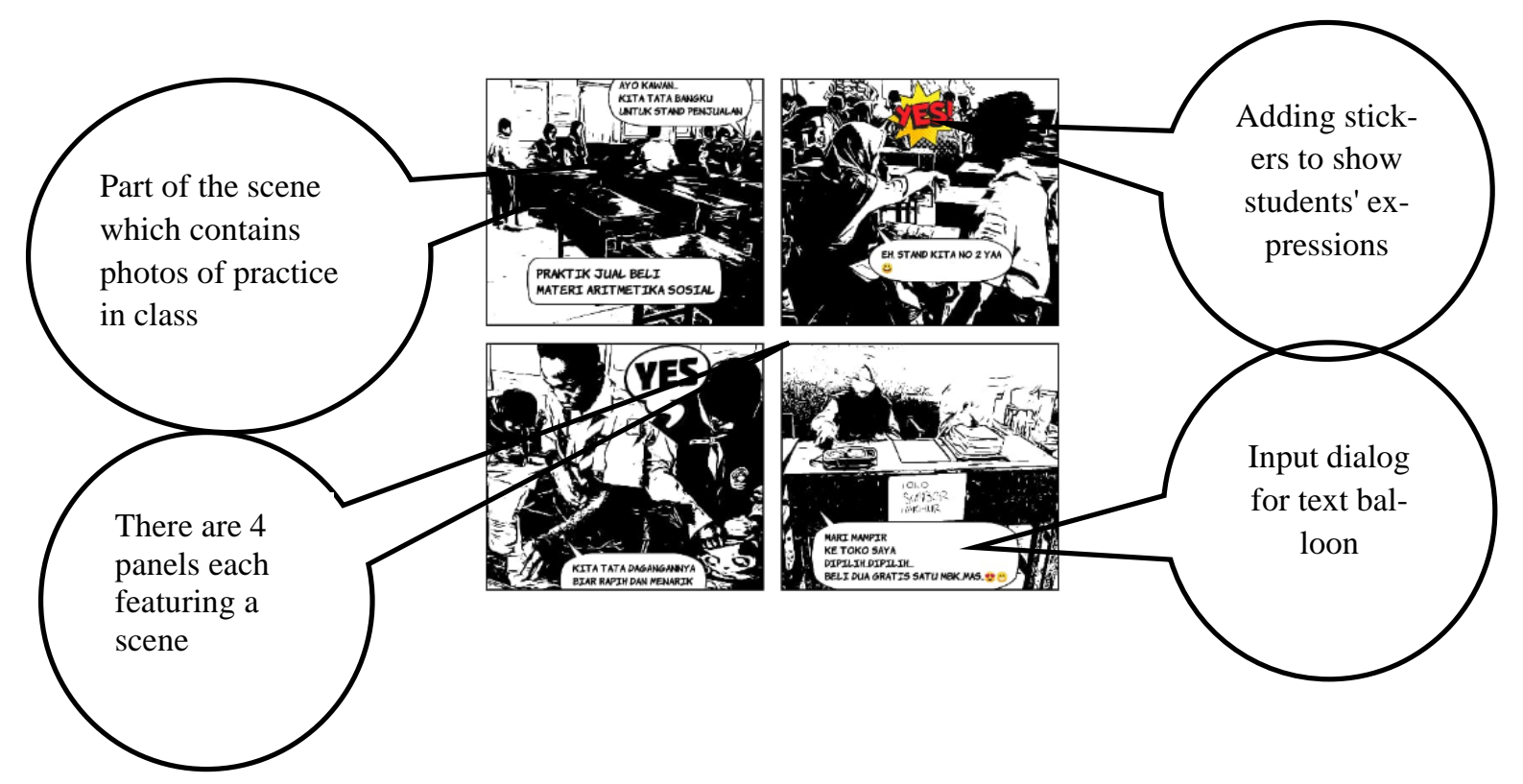

Figure 2. Prototype of the comic. 
In this comic media, pictures and stories are presented in an interesting plot so that it can attract students' interest in reading and capturing the messages in comics. This is an advantage that can be obtained when comics are used as a medium in learning. This is in accordance with the opinion of Recine (2013) that comics which contain images integrated into words will engage students more than the isolated images that fill textbooks. In addition, besides the objectives of learning mathematics about social arithmetic, developing character values about honesty in entrepreneurship is the main message to be conveyed through this comic. So, it is hoped that, through this comic, students can indirectly learn mathematics as well as train their character.

On this developing stage, the prototype was then evaluated in order to validate its feasibility. Two experts were involved to determine the validity of the product. The following table depicted the result of validity assessments.

Table 3

Validation Results from Material Expert

\begin{tabular}{lcc}
\hline \multicolumn{1}{c}{ Aspect } & Percentage & Criteria \\
\hline Content & $86 \%$ & Very feasible \\
Presentation and Interface & $93 \%$ & Very feasible \\
Language & $90 \%$ & Very feasible \\
Total & $89 \%$ & Very feasible \\
\hline
\end{tabular}

Based on the above table, the result from each aspect is in the "very feasible" criteria. In total, $89 \%$ came from the media expert. It means that based on the media expert the comic media has met the validity criteria.

Table 4

Validation Results from Media Expert

\begin{tabular}{lcc}
\hline \multicolumn{1}{c}{ Aspect } & Percentage & Criteria \\
\hline Dimension of the Comic Paper & $88 \%$ & Very feasible \\
Cover Design & $97 \%$ & Very feasible \\
Comic Content & $91 \%$ & Very feasible \\
Total & $93 \%$ & Very feasible \\
\hline
\end{tabular}

Material expert were asked to validate the comic from the aspect related to content but not limited to the aspect of dimension of the comic and cover design as well. The result for aspect of dimension, cover design, and content are $88 \%$ (very feasible), $97 \%$ (very feasible), and $93 \%$ (very feasible) respectively. It means that the comic media has met the criteria of 
validity. In total, based on material expert can be said that the comic is valid, with very feasible criteria (93\%). In conclusion, based on the expert's judgement, this comic media was valid.

\section{Limited field trial}

After getting the valid comic media, to know its practicality it is implemented in limited students. The limited field trial was conducted to 17 students. Students used learning comic media, then were given a questionnaire. The results of the questionnaire assessment (questionnaire) are intended to improve and perfect the media to be tested on operational field tests. The result of students' questionnaire showed the result of $82.30 \%$ (very good). Based on Table 1, this comic media has met the practicality criteria.

\section{Revising the initial product}

Based on experts (media and materials) and limited field trial, some suggestions and recommendation were gathered. Revision of the initial product was done. The following table are some points of revisions for the initial comic media.

Table 5

Revisions of the Initial Design

Comment/Recommendation

Subject Matter Expert

a. The initial instructions should be explained as there was a picture of the teacher giving the order to arrange a bench for the booth.

b. The character should be named.

\section{Media Expert}

a. The colour is too bold.

b. It is better to have a frame to make it interesting.

c. There should be colour variations.

\section{Revision Decision}

Subject Matter Expert

a. Slides are given by the teacher to give directions when students have to set up a booth.

b. b. The character's name is raised.

The revised version of the comic was then implemented to know the effectiveness of the media.

\section{Field trials}

Comic learning media was implemented to 34 students in this field trial stage. This stage aims to know the potential effect of the media for students understanding of social arithmetic concept. In this implementation, students were given the opportunities to demonstrate the story in the comics, so that they need to understand the content of the comics.

On the demonstration part, there were two groups, namely sellers and buyers. A total of 34 students were divided into 6 groups and each group consisted of 3 groups of buyers and 3 
groups of sellers. The instructions given to the seller group are carrying used goods packaging, price tags, toy money, sales memorandum and preparing the name of the store, while the seller group brought in the toy money as capital, and book purchase tables.

Activities were started from giving directions, structuring the sales stall, and other preparations. The core buying and selling activities were limited to 60 minutes with a whistle mark from the teacher. Finally, the presentation of each group reports the results of sales and purchases. Then, they were documented in photos and videos. Initial media products were in JPEG format photos and MP4 format videos that contained the buying and selling process. The results of students' work groups of buyers are shown in Figure 3.

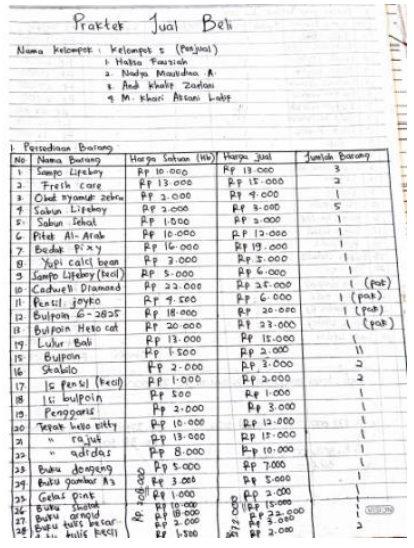

Table inventory and price

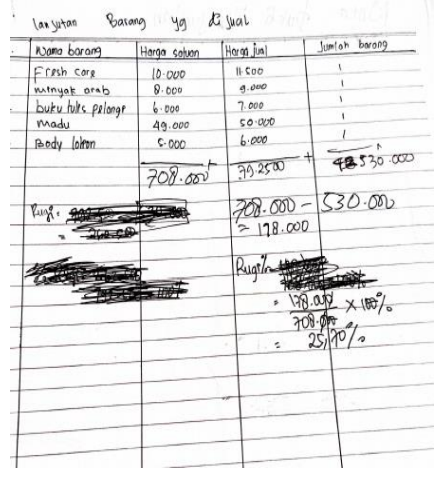

Group experienced a $25.70 \%$

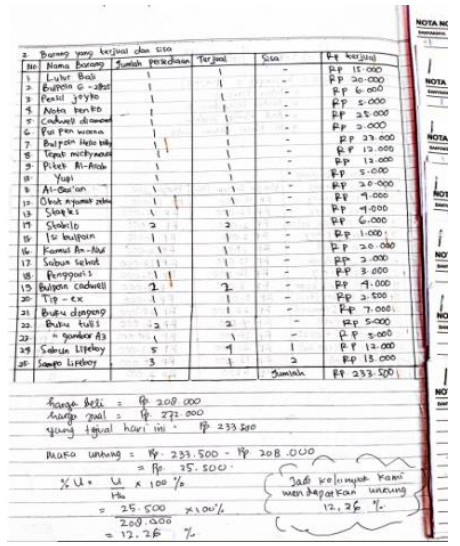

Group experienced a $12.26 \%$ gain

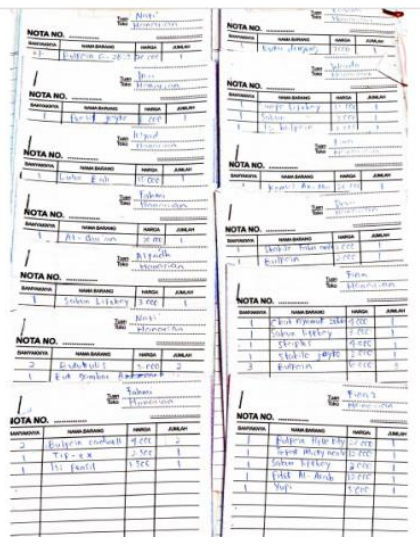

Evidence memorandum of sale of goods

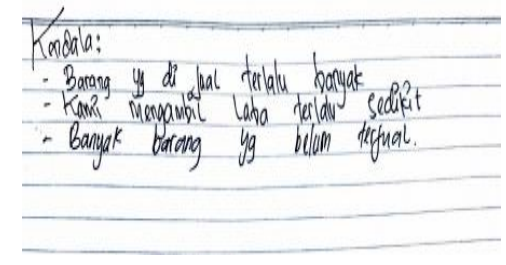

Obstacles during practice

Figure 3. Students' work (Buyer Group)

Based on the demonstrations of the buyer group, students experienced how to solve the problem related to social arithmetic such as price calculations, gain, and loss. Students who belonged to Seller Group also experienced making some mathematics calculations and solving problems related to price, gain, loss. Indirectly, through this simulation, students actually solve the real-life problems related to social arithmetic. Students learn and understand the case from the comic, then it is emphasized through demonstrations. 
Based on students questionnaire of this the field trials, it resulted $92.31 \%$ (very good). It means that this comic is practical based on field trials with 34 students. The evaluation of the comic effectiveness is defined by students test on social arithmetic topics after using the comics on their learning process as shown below.

Table 6

Students' Learning Achievement Using Comic

\begin{tabular}{ccc}
\hline Score Interval $(\boldsymbol{x})$ & Percentage of Students & Criteria \\
\hline $80 \leq x<100$ & $23 \%$ & Excellent \\
$66 \leq x<80$ & $68 \%$ & Good \\
$56 \leq x<66$ & $9 \%$ & Fair \\
$40 \leq x<56$ & & Poor \\
$0 \leq x<40$ & & Failed \\
\hline
\end{tabular}

From the above table, it is shown that there are $68 \%$ students are in "good" criteria and $23 \%$ students are in "excellent" criteria for their learning achievements. It means that $91 \%$ students achieve the learning results. It leads to the conclusion that this comic is effective to help students understand the concept of social and arithmetic.

\section{Revision of the final product}

In the final improvement of the comics media for buying and selling for social arithmetic subject, the researcher made some revisions. The final design of the comic was printed as shown in Figure 4.
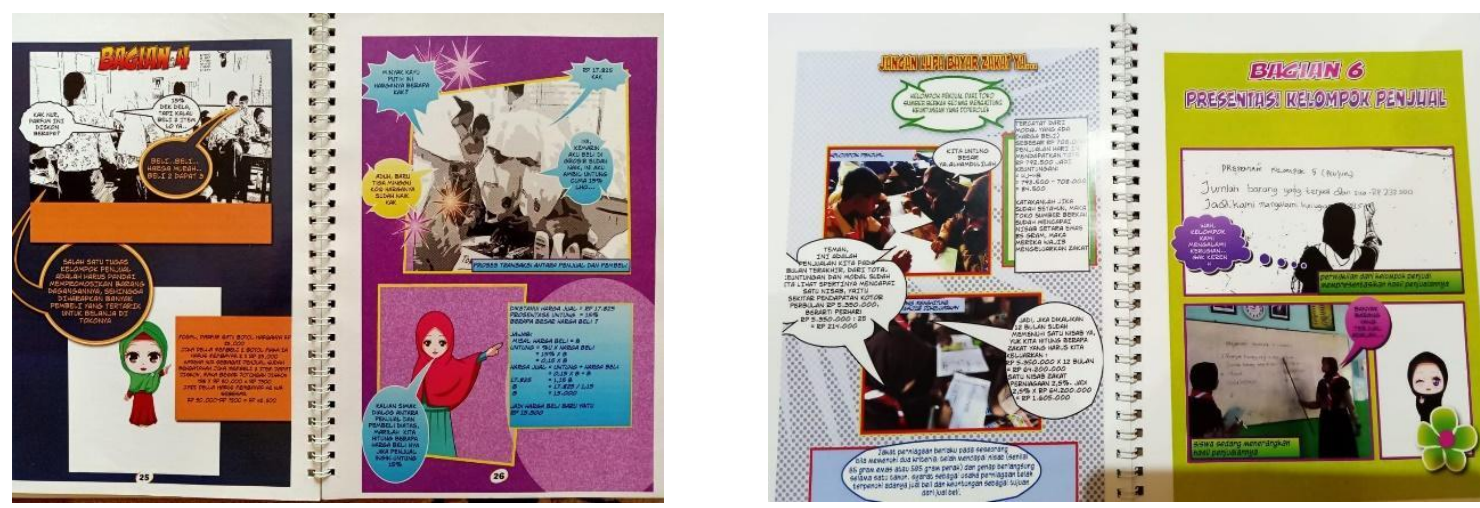

Figure 4. Final version of the comic. 


\section{Conclusion}

Based on the research result, a valid, practical and effective comic as a learning media for social and arithmetic has been successfully developed. The validity results involving media and educational experts showed that this comic learning media was valid, with the percentage of validity $93.6 \%$ are (very feasible) and $96 \%$ (very feasible) respectively. Based on the implementation of this media to VII grade students of MTs N 2 Mojokerto, an assessment by students as the media users showed that this media was practical with the percentage of $82.3 \%$ (very good) during the limited field trial, and $92.31 \%$ (very good) during field trials. The effectiveness of this media based on students' achievement result shows that $91 \%$ students were in "good" and "excellent" categories. It means that this comic learning media is effective. Based on these results, it can be concluded that this media was appropriate to be used as learning media on social arithmetic.

\section{References}

Adi Widodo, S., Turmudi, T., Afgani Dahlan, J., Istiqomah, I., \& Saputro, H. (2018). Mathematical comic media for problem solving skills. In Proceedings of the Joint Workshop KO2PI and the 1st International Conference on Advance \& Scientific Innovation (pp. 101-108). ICST (Institute for Computer Sciences, Social-Informatics and Telecommunications Engineering).

Akbar, S. (2013). Instrumen Perangkat Pembelajaran. Bandung: PT Remaja Rosdakarya

Bretz, R. (1971). A taxonomy of communication media. Educational Technology.

Borg, W. R and Gill, M D. (1978). Educational Research: An Introduction. New York: Longman

Fajriah, F., Salasi, R., Suryawati, S., \& Fatimah, S. (2019). Analysis of problem solving ability in social arithmetics. In Journal of Physics: Conference Series (Vol. 1157, No. 4, p. 042102). IOP Publishing.

Fauzan, A., Armiati, A., \& Ceria, C. (2018). A Learning Trajectory for Teaching Social Arithmetic using RME Approach. In IOP Conference Series: Materials Science and Engineering (Vol. 335, No. 1, p. 012121).

Hudoyo, H. (1990). Teaching Mathematics, Ministry of Education and Culture, Directorate General of Higher Education Project Development Institute for Education.

Indaryati, I., \& Jailani, J. (2015). Pengembangan media komik pembelajaran matematika meningkatkan motivasi dan prestasi belajar siswa kelas V. Jurnal Prima Edukasia, 3(1), 84-96.

Kristanto, A., \& Mariono, A. (2019, November). Development of education game media for xii multimedia class students in vocational school. In Journal of Physics: Conference Series (Vol. 1387, No. 1, p. 012117). IOP Publishing.

McVicker, C. J. (2007). Comic strips as a text structure for learning to read. The reading teacher, 61(1), 85-88.

Rasiman, Agnita Siska Pramasdyahsari. (2014). Development of Mathematics Learning Media E-Comic Based on Flip Book Maker to Increase the Critical Thinking Skills and Character of Junior High School Students. International Journal of Education, Vol.2, Nov 11, 2014.

Recine, D. (2013). Comics aren't just for fun anymore: the practical use of comics by TESOL professionals (Doctoral dissertation). 
Sulistyani, N., \& Retnawati, H. (2015). Pengembangan perangkat pembelajaran bangun ruang di SMP dengan pendekatan problem-based learning. Jurnal Riset Pendidikan Matematika, 2(2), 197-210.

Toh, T. L., Cheng, L. P., Ho, S. Y., Jiang, H., \& Lim, K. M. (2017). Use of comics to enhance students' learning for the development of the twenty-first century competencies in the mathematics classroom. Asia Pacific Journal of Education, 37(4), 437-452.

Wright, G. (1979). The comic book: A forgotten medium in the classroom. The Reading Teacher, 33(2), 158-161. 